\title{
Cultural Symbol of Akkorongtigi Tradition in Makassar Wedding Procession
}

\author{
Nursalam Nursalam ${ }^{* 1}$, Fitria Lapele ${ }^{2}$ \\ 1 Islamic State Institute of Ambon, Indonesia; e-mail: nur.salam@iainambon.ac.id \\ 2 Islamic State Institute of Ambon, Indonesia; e-mail: fitrialapele@iainambon.ac.id \\ * Correspondence
}

Received: 2020-04-22; Accepted: 2020-12-12; Published: 2020-12-30

\begin{abstract}
This research examines the cultural symbol of akkorongtigi in Makassar's wedding tradition. The research method used is qualitative with semiotics and the theory of symbolic interactionism from Blummer are used to analyse the data. The data of this research are the documentation of bridal akkorongtigi activities and verbal utterances which were transcribed into the text. Besides, data collections are obtained through gathering documents, in-depth interviews, and observations (field recording, recording, and photo shooting). There are four steps of data analysis; (1) reduction, (2) presentation, (3) research finding, dan (4) conclusion. The results of this research show that there were four cultural symbols in akkorongtigi, namely the symbol of hope, the symbol of religion, the symbol of glory, and the symbol of togetherness. Besides, the representation of the implementation of the akkorongtigi tradition is supported by two things: verbal and nonverbal aspects. The verbal aspects are represented by the recitation of the prayer, while the non-verbal aspects are represented in the use of pillow, henna leaf, rice, candle, praying mat, and banana leaf.
\end{abstract}

Keywords: Akkorongtigi; cultural; semiotic perspective; symbolic; wedding.

Abstrak: Penelitian ini bertujuan mengkaji simbol budaya akkorongtigi dalam tradisi pernikahan masyarakat Makassar. Pendekatan yang digunakan adalah pendekatan semiotik. Metode penelitian yang digunakan adalah metode kualitatif dengan semiotik dan teori interaksionisme simbolik dari Blummer sebagai alat analisis data. Data penelitian ini adalah tuturan verbal yang ditranskrip ke dalam bentuk teks. Pengumpulan data yang digunakan adalah studi dokumentasi, wawancara mendalam, dan observasi (pencatatan lapangan, perekaman, dan pemotretan). Tahap analisis data dalam penelitian ini melalui empat tahap, yakni tahap (1) reduksi, (2) penyajian, (3) temuan penelitian, dan (4) penarikan kesimpulan. Hasil penelitian menunjukkan bahwa simbol budaya dalam budaya akkorongtigi ada empat, yakni simbol pengharapan, simbol relijiusitas simbol kemuliaan, dan simbol kebersamaan. Selain itu, representasi pelaksanaan tradisi akkorongtigi didukung dua hal yakni aspek verbal dan nonverbal. Aspek verbal mencakup penggunaan bahasa seperti doa, sedangkan aspek nonverbal mencakup objek perlengkapan seperti bantal, daun inai, beras, lilin, sajadah, dan daun pisang.

Keywords: Akkorongtigi; budaya; pernikahan; persfektif semiotic; simbol.

\section{Introduction}

Symbols are communication markers that can be understood through individual empirical knowledge and experience. Symbols have an implicit or explicit message as a manifestation of reality. They do not show natural meaning with the markers because it is conventional (Astika \& Yasa, 2014, p. 23). Since the first symbol used as a communication system in the traditions and culture of society, 
symbols can be mean as self-expression that is universally understood by others (Hide, 2003, p. 77). Symbols are related to certain objects outside the sign itself. Therefore, symbols have an external relationship with images and content through a point of comparison, even though they have multiple language representations, but they don't have to confuse (Vischer \& Yanacek, 2016).

Symbols can be verbal and nonverbal. A verbal symbol is in the form of language utterances, while a nonverbal symbol refers to certain objects. The verbal symbol is interpreted as connotation, while the nonverbal symbol can be interpreted through language by referring to a nonverbal object or sign as a code. The empirical knowledge is very supportive in the understanding symbol so that each individual has a different perspective and interpretation. In the process of interaction, a symbol is a creation that can be manipulated by the individual. It can be used as a social communication system in understanding culture because symbols and culture are interrelated. Even though, everyone's understanding of cultural symbols varies due to differences in beliefs, values, attitudes, world views, and social organizations (Porter \& Samovar, 2004). Moreover, culture is a manifestation of verbal and nonverbal symbols. It can be represented through tradition and binding habits in the social system of society. Society and culture have a dialectical relation. The purpose of culture created by a human is a basis or guidelines from human life (Leuape \& Dida, 2017, p. 148). It has become the basis of human thought so it is considered central in life. It can also determine the worldview, mythology, and cosmology of a society in daily life, both personally and socially (Saryono, 1998, p. 39). Therefore, culture is a reflection of the social life of people with various phenomena of global and contemporary culture (Wikandaru, Lasiyo, \& Sayuti, 2018).

Three forms of culture have been the frame of people's lives, namely (1) thoughts, ideas, and norms, (2) people's habits that are bound in norms, and (3) objects which contain cultural values as symbols of identity (Wahid, 2016, pp. 5-6). Similarly, in the culture of Makassar society, there are traditions of Makassar society that have bound its social life one of them is called akkorongtigi. Akkorongtigi (bridal night) is a tradition in Makassar marriage that is sacred. Usually, the process is done a day before the wedding reception. Akkorongtigi is the initial stage of marriage before the wedding ceremony or reception. Akkorongtigi is done to get happiness because it is considered a process of self-purification through prayers that are embedded in the process. Akkorongtigi in the Bugis language is called mappaccing (bridal night). This tradition has become a social-cultural system that binds the people of Makassar. A cultural symbol in the akkorongtigi tradition has noble values and messages. Therefore, mind, self, and society are needed to internalise the cultural symbols in the akkorongtigi tradition as social networks to build social and cultural communication (Prasanti \& Sjafirah, 2017).

Research on the akkorongtigi tradition has been carried out. First, Nursalam (2016) about a review of Islamic law about the Makassar traditional marriage procession in Somba Opu District, Gowa Regency. The results showed that Makassar traditional marriage procession did not violate the teachings of Islam. The marriage process like Akkorongtigi is seen as a special symbol to gather and pray for the bride and groom. Second, research is conducted by Rappe (2016) on cultural values at the mappaccing (bridal night) ceremony in Tibona village, Bulukumpa District. The results displayed that mappaccing (bridal night) is one of a series of sacred wedding processions. being customary, the procession of mappaccing (bridal night) contains noble values that have become a legacy of past societies. Besides, this procession can foster hospitality between families that present during the process. Third, research conducted by Putri (2016) on the meaning of the message of the tradition of mappaccing at the Bugis Pangkep traditional wedding in Talaka sub-district of Ma'rang. The results showed that the preparation and procession in the mappaccing ceremony is a Bugis Pangkep custom whose implementation used mappacci leaf. In this procession, some prayers contain hope for the happiness of the bride and groom arranged in a summary of the words of the nine kinds of equipment, such as pillows, silk gloves, jackfruit leaf, banana shoots, pacci leaf, rice, candle, pacci containers, brown sugar, and coconut (Putri, 2016).

The three kinds of research mentioned above are generally different from this research. The focus of the first research is to examine the views of Islamic law on the marriage process in Makassar custom 
in general. In contrast, this research focuses on studying cultural symbols in the process of akkorongtigi tradition as a part of Makassar traditional marriage. The second research focused on examining cultural values in mappaccing. Mappaccing in the process of Bugis traditional marriage is certainly different from akkorongtigi in Makassar traditional marriage so it has a different concept of values and cultural symbols. The third research focuses on the meaning of the tradition of Mappaccing, while the focus of this research is the cultural symbols that appear in the Akkoringtigi tradition, verbally, and nonverbally. This is what underlies this research that needs to be done for several reasons (1) akkorongtigi has cultural symbols that reflect human expectations so it needs to be studied deeper, (2) research on akkorongtigi cultural symbols will be a place to care for cultural values and local wisdom of Makassar, (3) research on akkorongtigi culture will support the process of cultural scientific development, and (4) through research on akkorongtigi culture, it will enrich the diversity of cultures and traditions in Indonesia.

Furthermore, this research used a qualitative method that has the aim to describe interactive relationships and reality comprehensively to gain an understanding of the meaning (Sugiyono, 2010). Meanwhile, the method used is the semiotic analysis method. It emphasises signs that are interpreted from language and events (Sulistyorini \& Andalas, 2017, p. 42). The analytical theory used is Blummer's symbolic interactionism theory which emphasises the interpretation of social reality through symbols understood in communication behavior or ritual processions (Sulaeman, Rijal, Malawat, \& Sere, 2020, p. 9). Data collection of the study includes documentation, in-depth interviews, and observations (field recording, recording, and photo shooting). The data analysis stages in this research are carried out in three stages, namely reduction, presentation, and conclusion (Miles \& Huberman, 1992, pp. 16-18). First, the reduction stage is carried out in four ways, they are (1) transcribing speech data into written text, (2) data that has been transcribed and then identified according to the purpose of the study, (3) classified the data processor based on the research objectives namely, cultural symbols in the akkorongtigi tradition, and (4) finding the meaning of the data that has been previously classified. Second, the presentation stage, which presents the data in tabular form. Third, the stage is deriving the conclusion by re-verifying the initial data as the final stage in this study.

\section{Akkorongtigi Tradition in Makassar Society}

Akkorongtigi has become a tradition of Makassar society which is believed to be a cultural heritage of the past. This tradition is not only a ritual that symbolises social identity, but it is believed to be the cultural system that can bring good to the bride and groom. Almost every aspect of life is ruled by culture and tradition for the sake of changing behavior for the better (M'jamtu-Sie, 2008, p. 93). This is what makes akkorongtigi considered a sacred process that must be done in every marriage in Makassar. That tradition is in line with the principle of Makassar society who upholds siri (shame) so that they must cleanse themselves physically and mentally through the process of Akkorongtigi. It can be seen through traditional instruments and processions used such as sarong and henna leaves which have symbolic meaning to cover the nakedness and beautify the bride and groom. The values in the tradition are used as a view of life that underlies the behavior of Makassar society.

The akkorongtigi process is basically carried out in the bride and groom's house. It is done at night before the wedding ceremony and the wedding reception takes place. It begins with a barzanji or prayer process led directly by a traditional leader. Then, guests who attended, such as the family and relations of the bride and groom, participated in giving prayers which are marked by the use of henna leaves on the bride's hand. It shows the existence of cultural symbols in the akkorongtigi process.

\section{The meaning of Cultural Symbols in Akkorongtigi Procession}

According to this research, several cultural symbols are found in the akkorongtigi tradition and described as follows. 


\section{The Symbol of Hope}

The akkorongtigi is believed by the Makassar people not only as a ritual but as a symbol of hope for the bride and groom. Through this process, the bride is expected to get happiness and blessing in navigating the household ark. It showed the communication behavior that is sacred and meaningful even though in the process of this tradition only used ordinary objects. However, the significance of the symbol is not of physical significance. The symbol is reflected in the following figure 1 .

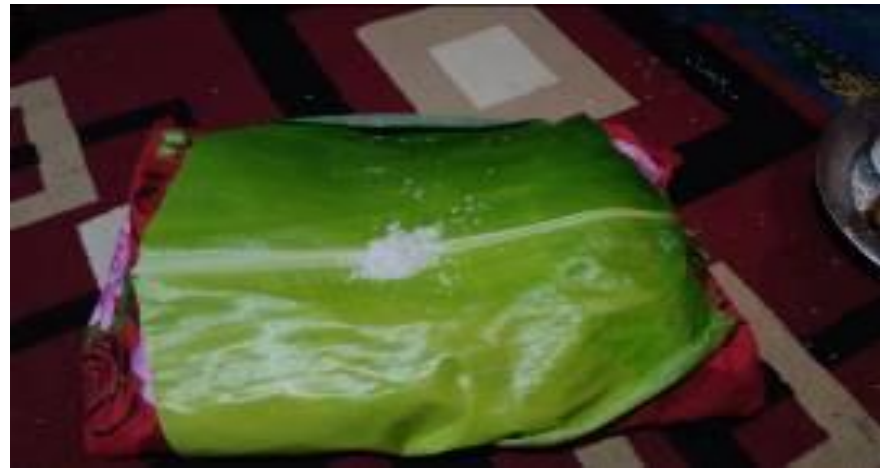

Figure 1 Banana Leaf

Figure 1 is leko unti (banana leaf) used during the akkorongtigi process. It is a symbol of hope for the bride because the banana leaf used its young shoots. Shoots of banana leaf in Makassar society is believed to have a special philosophy. Banana leaf also symbolises the hope that the bride and groom always get endless sustenance. The concept is in line with Pierce's explanation that symbols as markers have an arbitrary conservative meaning which is accepted through the beliefs of ritual performers (Astika \& Yasa, 2014). This is confirmed by Daeng Ngila (Personal Communication, October 14, 2019) as the imam in the marriage process, "pamminasana cappak leko unti baji tongi katte iang tong ujung singkama menonjol $i$ rate $d u d u$ (The hope for the using of banana leaf is that they will always get high blessing and supreme)."

Banana leaf had a deep meaning when used in the akkorongtigi process. It is placed on a pillow that symbolises continuous life. It will never fall before other shoots appear. Besides, the banana leaf had many benefits for living things. It can be a source of food either for humans or animals. Therefore, it described human hope that the life of the bride and groom will continue and can be useful in everyday life.

There are many hopes and prayers embedded during the akkorongtigi process. The moment is a celebration that needs to be grateful for with family and bridegroom. Hopes and prayers had become the symbols of life through the ritual process performed (Hide, 2003). The use of banana leaf shoots is the part of the hope for the bride and groom that their new family is full of blessings and abundant fortune. It became a symbol of blessing for the bridegroom that should exist in the process of akkorongtigi to maintain the values of wisdom and hope.

The finding above is in line with the statement of Sulistyorini \& Andalas (2017) that tradition is related to the belief, thus it is carried out with a special attitude through ritual symbols. Moreover, the opinion of Ridwan, et.al (2020, p. 709) stated that tradition helps people recognise their identity and build social communication through their belief in their culture and religion. The akkorongtigi is believed by the Makassar society not only as a ritual but as a symbol of happiness for the bride and groom. Through this process, the bride is expected to get happiness and blessing in navigating the household. It shows the communication behavior that is sacred and meaningful (Sulaeman \& Rijal, 2018, p. 292).

\section{The Symbol of Religious value}

Akkorongtigi tradition is believed to be a mediation process to remember God so that there are religious values in that process. It can be seen in figure 2 . 


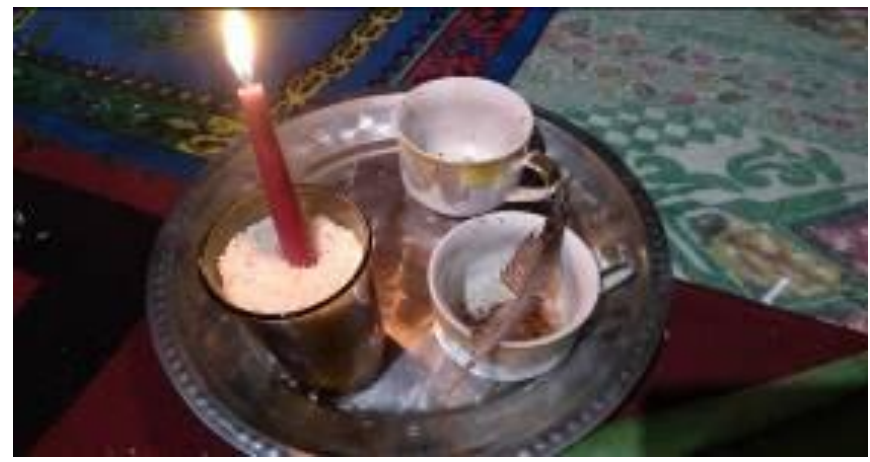

Figure 2 Jakjakkang/rice and candle

Figure 2 shows the use of rice as jakjakkang (dowry). The rice used has a special dose as much as sigantang (4 liters). The amount is based on the belief that humans are essentially created from 4 elements of life, namely land, water, air, and fire. The belief is carried out jointly by the Makassar society because Blummer considers the ritual process to be a form of communication that binds all society's behavior. It is supported by the following statement of Daeng Ngila (Personal Communication, October $14,2019)$ as the cultural leader in the marriage process.

Akkorongtigi mappaccing pamminasa bajik...niak jakjakkang berasa nasigantang (4 liter) nasaba punna nipamange ri kaniakkanga battuki ri appaka pepe, angin, butta, jekne battuanna angjo appaka passiddakka kabusu.

Translation:

Akkorongtigi is hope for goodness in which 4 liters of rice describe the origin of human creation from the four elements namely fire, wind, land, and water as alms.

This statement means that human is created by God from various perfect elements. Humans were born with all the perfections and weaknesses so that they must not forget to give contributions as a way to give thanks. Rice had been a source of human food for survival. This obstinacy can be applied by the bride and groom to become a tough and honest person with a white heart like rice. Another symbol that can be seen in figure 2 is the use of a candle. One candle symbolised that God is the only one who gives guidance and illumination in human life. The candle is light so that people did not get lost in the dark. Through this light, humans are expected to be able to walk straight in their life. This symbol signified a form of the way humans believe in religious teachings as their beliefs (Sulaeman et al., 2020). This statement is supported by the following expression of Daeng Ngila (Personal Communication, October 14, 2019).

Angjo liling sikamma lebbakji angjo tawwa punna sambayangki nanjongjo kammaangjo maknassana meyakinkan allah itu satu...tapi pamminasa barang gappa tongji singara.

Translation:

The candle is interpreted as when we are praying, we reach out the forefinger to prove the belief that God is only one... then hope to get a bright light.

The use of the candle symbolised a representation of the faith of Makassar people in the culture and traditions that they have carried out so far. Symbol as a sign that connects them with the transcendental realm of belief through various forms of ritual (Wahab, 2011, p. 83). This proved that culture and religion had theological relevance in the hearts of their believers. This symbol signified a form of humans' belief in religious teachings and interrelated with cultural values. Religion is considered final, universal, eternal, and no change. Whereas, culture is particular, relative, and temporary. In Indonesia, religious teaching is mingled with cultural values (Umar, 2020, p. 72). Therefore, culture and religion must support each other even though they have different processes.

The symbolic representation in akkorongtigi shows support for the religious process. This symbol can be a prayer and hope for the bride and groom. Likewise, the use of candles in akkorongtigi has the 
hope for the bride and groom to get bright light in their life so that they always believe in Allah SWT and free from all worldly temptations that can mislead their lives.

Humans are servants of God who must worship and surrender to Him. Humans must have faith in Him. Therefore, the bride in living the household must be based on faith and piety to Allah SWT. These messages were implied in the akkorongtigi process which is marked by the use of prayer rugs in figure 3.

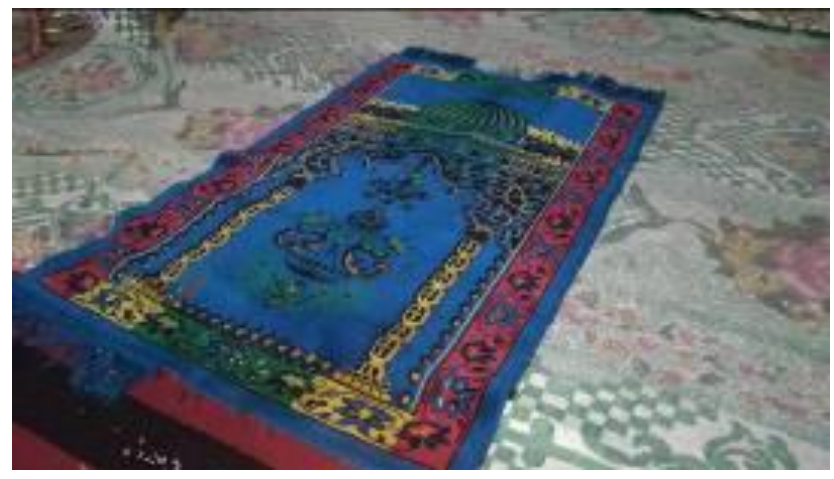

Figure 3 Prayer rug

The prayer rug is a symbol of prayer equipment. It is used as a place of prostration to worship Allah SWT. This thing showed humility by prostrating that only Allah has the highest degree. This is the expectation of the bride and groom to be persons of inferiority and obedience in praying to remember Allah. The prayer rug in the context of the sign is causal because it showed a natural relationship with the sign which is the place to prostrate them before God. Makassar society believes that blessing in the family is inseparable from the will of God as the creator. Therefore, to be a harmonious family requires faith and piety by being devout in worshiping God.

The implementation of the akkorongtigi tradition represented the implementation of Islamic worship. This indicated that religion and culture are interrelated in shaping human attitudes. Besides, the vision and mission of Islam is a blessing for the universe, so the acculturation with culture and tradition is also oriented to the benefits of human life and adjust to the intentions and objectives of sharia (maqashid al-syari'ah) (Umar, 2020). This principle is held by the Makassar people in their lives that culture is part of a religion that can coexist because it has the same goal to make people wiser. Although in the process, they have different ritual procedures, both of them become the center of mediation to consider prayer and hope in the harmonisation of society. The use of cultural symbols in the akkorongtigi tradition was able to represent the identity of the local wisdom of the Makassar society. It indicated that people are always trying to make cultural interactions that are built on religious principles that they believe in.

\section{The Symbol of Glory}

Makassar's social system is interrelated with the cultural system it adopts. In the social order, the Makassar society is bound by the social values that underlie it in attitude and action. Makassar people are familiar with the concepts of siri and pacce (a race of shame and pity) which are upheld in society and culture. Both values become self-identity even though life is sometimes at stake so as not to lose siri as self-esteem. However, behind these principles, the people of Makassar are taught the values of wisdom by their ancestors to glorify one another. These values can be seen in the cultural system and traditions that have been growing in society. The same is true in the implementation of the akkorongtigi tradition. The values are represented in Figure 4. 


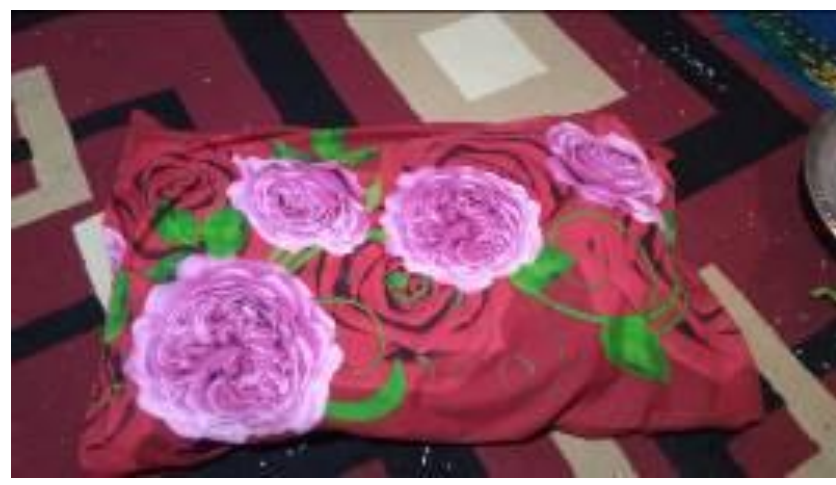

Figure 4 Pillow

Figure 4 is a pillow that is believed to be a symbol of glory. Pillow made of cloth, filled with cotton, covering during sleep where the head is the noblest part of humans. Thus, the pillow symbolised honor, glory, and dignity. Therefore, it is hoped that the prospective bride and groom will always maintain their dignity and respect for each other (Rappe, 2016). A pillow was a human headrest that has the highest degree and position among other body parts. Humans had a high level and dignity that must be maintained. This hope must be maintained by the bride and groom to keep their dignity in the family. Both partners must glorify each other with their respective roles. A wife must obey her husband by maintaining her husband's glory. And vice versa, a husband must glorify his wife through verbal attitudes and behavior. In establishing a family, the bride will face many challenges. Even though they already had responsibilities towards their families and also respect for their parents. The bride must still glorify her parents with all the humility they had.

The values of wisdom above are essentially taught in Islam. It confirmed that the tradition is following religious teachings that taught the good that determined behavior in making decisions (Aisah \& Albar, 2020, p. 4). Humans are the most perfect creatures among other creatures. Perfection is a glory that must be maintained through attitude and speech. However, humans must still be tawaddu' (humble) to God. This attitude and sincerity are also represented through the leko korrongtigi symbol (henna leaf). It is a symbol of purity of self which was finely ground and placed on the bride's hand. It can be seen in figure 5 .

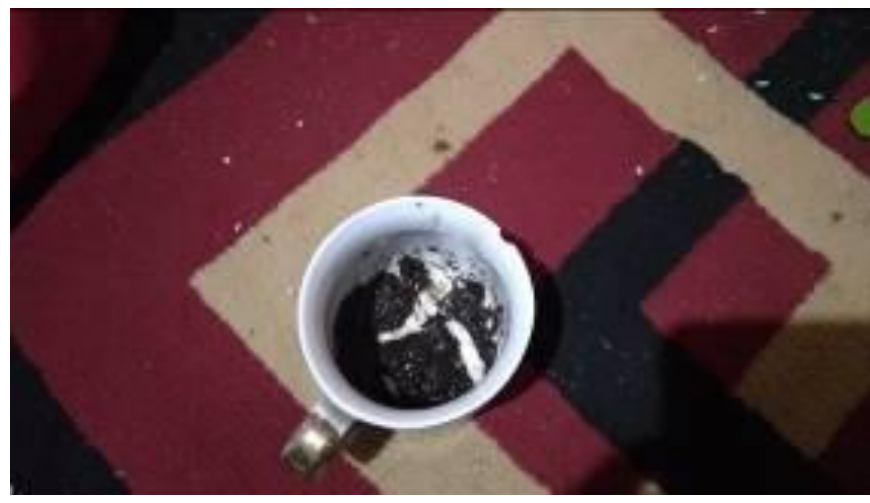

Figure 5 Henna leaf

Henna leaves in the akkorongtigi process represent holiness. So far, henna leaves are often used to beautify nails so that they make the appearance of those who use them more attractive. The hope that is desired through this symbol, the bride and groom can maintain a pure self and attitude. The purity is not only limited to inner purity, but includes physical purity through a clean life. Living clean is an Islamic recommendation that symbolizes one's faith. Cleanliness is very important for maintaining health. This is what is expected for the bride to foster her household to maintain the purity or personal hygiene both physically and mentally. This tradition is carried out with the deep conviction of the 
people of Makassar to preserve the existence from the claims of other cultural owners (Sulaeman \& Rijal, 2018).

Another philosophy that can be taken is the use of henna leaf in the process of akkorongtigi that henna leaf is placed in the hands of the bride by a family or pregnant woman who has a good household life. The bride is expected to have the same family life as these people. The use of henna leaf is a way for Makassar people to glorify their brides with their hopes through the akkorongtigi process. The challenges faced by brides in their household are numerous, so the tradition performed a prayer to God through the culture that symbolised spiritual and physical purity.

\section{The Symbol of Togetherness}

The implementation of the akkorongtigi tradition became a moment of friendship between the bridal families. Akkorongtigi tradition as a model for identity to build, foster, and preserve the spirit of solidarity, togetherness, cohesiveness, and unity (Sulaeman, Mahriani, \& Nurdin, 2019, p. 214). Besides gathering with family, they also gave prayers to the bride so that their families received happiness and blessings. Akkorongtigi tradition is not only a moment of the gathering of families, but this togetherness is enjoyed by everyone present. They came in droves to enliven the process as a celebration to be grateful for. The principle of siri and pacce (shame and pity) held by the Makassar society made them help one another and gave prayers, especially to the bride and groom. Guests who are present during the akkorongtigi process came to offer prayers so that the bride and groom are given a harmonious and blessed family while undergoing their new family.

Another form of togetherness shown by the Makassar society in the akkorongtigi process assists the bride's family. The assistance is in the form of providing groceries for a celebration that can ease the burden on the family during the wedding process later. This had been done for generations. This togetherness represented the principle of pacce to the bride and groom to help each other. Moreover, the marriage culture of Makassar society is certainly different from other cultures in Indonesia. Makassar society knew the tradition of panaik money. Panaik money had become a moral burden for most of the people of Makassar that the people of Makassar help each other to succeed in the wedding celebration of the bride and groom in the akkorongtigi process. These values are still maintained by the Makassar people as ancestral heritage in caring for their social life. This process continued to be maintained by the Makassar society through the religious process because it did not contradict Islamic law. Therefore, culture and religion had historical and social correlations as well as mutual support (Hartono \& Firdaningsih, 2019, p. 366).

\section{The Representation of Nonverbal Signs}

The representation of nonverbal signs in the akkorongtigi tradition is shown through non-linguistic behavior as part of the ritual process (Sulistyorini \& Andalas, 2017). As a sacred process in a series of marriages, the akkorongtigi tradition is carried out meaningfully to maintain the sacredness of the tradition. This can be seen through a series of stages carried out by traditional advice called anrong bunting. The process is described below.

\section{The Interpretation of Akkorongtigi Stages}

The akkorongtigi stage began with pregnant women by placing a henna leaf in the bride's hand. Then, again sprinkle rice on the bride's hand. During this process, pregnant women recite prayers for the bride and groom. Anrong pregnant in Makassar society is considered as a marriage guide to tell wedding tips that must be fulfilled by bride and groom. This is inseparable from the experience and hopes pinned later on brides in undergoing the household to become a harmonious family. This process can be seen in figure 6 . 


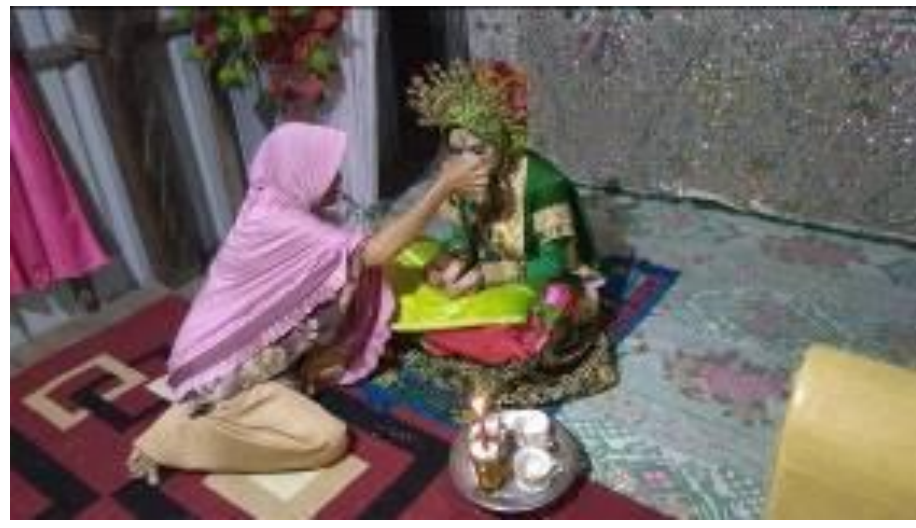

Figure 6 Stage of akkorongtigi

The implementation of akkorongtigi as shown in the picture above essentially begins with anrong bunting (marriage counselor). This procession had become a general provision that must be carried out to perfect the ritual. Besides, another hope was pinned by pregnant women when candles were raised above the bride's head so that later they will get a bright life in living a new life in their family. Alternately the family and traditional advice continue the process of akkorongtigi in the same way even though the prayers that are pinned to the bride are different. In the customs of the people of Makassar, especially the village of Bontobila, the number of people who give korrongtigi or pray for is odd, that is, at least five people or even more than ten people.

The goal is the same so that the bride and groom always get the blessing of life from God and be able to imitate the harmonisation of the family that gave the sacred blessing. The arrival of families giving prayers in the process of akkorongtigi is proof of family harmony that has been framed in a tradition of a family heritage that continues to survive until now. Society creates meanings that describe language and symbols through akkorongtigi rituals by putting hope in living their lives (Sulaeman, Kamaruzzaman, \& Malawat, 2019, p. 429).

The implementation of akkorongtigi became a religious symbol in Makassar society. The representation of religious values is not only limited to verbal speech in prayer, but this process was explained through the stages of the implementation. When implementing akkorongtigi, the bride and groom are asked to face east as a source of human life, the place where the sun rises. The final stage in the implementation of the process was closed with a prayer by family or traditional advice that is present as a form of gratitude to Allah SWT.

\section{The Interpretation of Akkorongtigi Object Symbols}

Parallui nipakalabbiri toanaya nasaba katte kioki battu siagang angjo kammaya sekre sipak bajik mange riparanta tau.

Translation:

Adoring the guests is very important because guests come to fulfill our calls, besides it reflects good qualities to all humans (Daeng Tommi, Personal Communication, October 14, 2019).

The symbol of akkorongtigi ritual can also be seen from the offerings served in the tradition. In general, in the akkorongtigi process, various types of cakes are placed on the bosara. Bosara is the king's food equipment since ancient times, which is still used by the people of Makassar in various celebrations. Cakes that are usually served to guests and families have philosophical meaning that is meaningful to live such as onde-onde, cucuru', and sponge cakes. The cake is a symbol of sweet life that is expected to be achieved by the bride and groom so it needs to be presented to complete the execution of akkorongtigi. The cakes served in bosara are the way Makassar's people treat guests like kings. Manner and custom are two different things, but in the context of life can be done simultaneously. This principle had been held by the Makassar society so that it is always appakalabbiri (glorifying) the guests. 
As the previous discussion that in the implementation of akkorongtigi there are objects of equipment used to complement the tradition. The use of equipment such as pillows, henna leaf, rice, candles, prayer rug, leko unti became the representation of the hope of a bride to be a family blessed by God. Another meaning is obtained that it is a way of purifying the body and soul of the bride in undergoing her new family with a partner. In general, during the implementation of the akkorongtigi process at that time several other objects are not used in the process such as kaddo minyak, silk sarong, and lamming. Kaddo Minyak was a kind of food such as a cone which is often served with free-range chicken as a symbol of ritual in various celebrations in Makassar. However, the implementation of akkorongtigi at that time is not provided because there is no barasanji and appatamma (khatam Quran completion of Qur'anic recitation) process for the bride. Then, the layer of silk sarong is also not seen as an object of traditional equipment as a symbol of shame and moral closure. The custom process that started to shift made the object chain can be replaced with other objects. Culture is a transactional process that is lived through habits and subject matter that is dynamic. Furthermore, there is no more lamming (traditional gate) made of bamboo woven wedding chairs (Miedema \& Roebben, 2008, p. 484). Lamming is specifically a symbol of bridal nobility so it is currently only used for families of brides who have high social status. This is following Daeng Tommi's (Personal Communication, October 14, 2019) explanation below.

Lamminga sikammang anne nakana mangkasaraka kullemi nisambei sajadah iareka kamara bunting tampa akkorongtigi siagang baji.

Translations:

Moreover, the use of lamming has been interpreted by the Makassar society as a prayer mat or bridal chamber where akkorongtigi was held which was considered not to reduce the sacred process of akkorongtigi.

\section{The Representation of Verbal Signs}

Verbal signs in the implementation of akkorongtigi tradition referred to elements of language use. The language element is implemented through prayers that are spoken orally by pregnant women, married priests, and other families who come during the process. In general, the prayers offered by Anrong Bunting and the priest of the bride are different, but have the same intention and hope that the bride will have a better life in her new family. This is evidenced through the speech of the bridal priest and the following prayer quote.

Tena sangkamma-kamma anjo pappaladoangangi sekrea taukamma angjo nakke tena maraeng tallasanaji na berasaji kupakammangi angjo... sikammaangjo tallasanna karaeng labbuangi umurukna...naangjo dallekna bellaya karaeng kipakammani karaeng angmania kisareangmi karaeng.

Translation:

The prayers offered by each person are different. I just say a prayer about her life while sprinkling rice on her... so that her life is given a long life... the faraway fortune came closer and the near fortune will be given.

The expression of prayers is believed in the people of Makassar as a process of getting closer to God. The Makassar people believed that the power of prayer can give them a blessing in their lives. Prayers are delivered through the Makassar language and Arabic as a complement to the stereotypical and traditional process of tradition (Sulistyorini \& Andalas, 2017). The prayer is pinned to God along with the symbol of the object used in the akkorongtigi process, such as when sprinkling rice and henna leaf to the bride by anrong bunting and the bridal priest. Prayer is a process of vertical communication to God Almighty to rely on oneself and all hopes. Praying reflects the maturity of the soul and reflects the harmony of life in the world and the hereafter (Rappe, 2016). 
Many hopes are desired through prayers to Allah SWT. It is evidenced by the word "his life" in the previous prayer quote. The word 'life' has also been identified as a symbol of hope for the bride and groom. In general, the word "life" is interpreted as a condition of oneself which includes both physical and spiritual. However, the word has a broader meaning. In the prayer quote, the word "life" represents self-blessing for the bride that includes long life, happiness, sustenance, and harmonious family integrity. Therefore, in akkorongtigi, prayer becomes a medium or means of communication to convey the hopes that the bride and groom want after marriage.

The akkorongtigi tradition is characterised by symbolic interactions. It can be seen in the prayer process. The customary leader prays for the bride and groom and spread rice to them as a symbol of life. Rice is interpreted as a symbol of life. It makes the akkorongtigi process more sacred. Therefore, this dynamic is in line with the concept of Blumer's interactionism theory that social reality is created through the interaction of symbolic meanings (Sulaeman \& Mulyana, 2016, p. 37).

\section{Conclusion}

Based on the results of this study, there are four cultural symbols in the implementation of the akkorongtigi tradition of Makassar society, namely the symbol of blessing, the symbol of religious value, the symbol of glory, and the symbol of togetherness. The four symbols are shown through the use of non-verbal objects of traditional devices, such as pillows, banana leaf, henna leaf, prayer rug, rice, and candle. The symbol of hope represents the wish of the bride to get happiness and blessing in her household. Hopefully, it can be useful for others in their social life. The symbol of religious value represents that culture is part of religion to remember God through available verbal symbols. In the implementation of the akkorongtigi tradition, it is necessary to remember God as the creator through prayer or a ritual process that is carried out. The symbol of glory explains that the Makassar society has high so they are obliged to maintain their dignity. This dignity is reflected in siri na pacce (shame and pity) which is the life principle of Makassar society. The symbol of togetherness represents that the implementation of the akkorongtigi tradition is a moment of friendship between families to strengthen bonds in the family. Togetherness is shown through the attitude of helping each other make the wedding party a success and helping materially.

Besides, the implementation of the akkorongtigi tradition is supported by two things namely verbal and nonverbal aspects. Verbal aspects include prayers delivered by pregnant women and wedding priests so that the bride will get a blessing in her family. Meanwhile, nonverbal aspects include objects or tools that support the implementation of akkorongtigi such as pillows, banana leaf, rice, candle, prayer rug, cakes which are cultural symbols in the Makassar wedding tradition. This research is expected as a form of preservation of Makassar's culture and traditions so that there is no modification in values by foreign cultural influences. The recommendation of this research is to use different theories and methodological contexts such as the ethnographic method of communication to uncover the phenomenon of tradition and its position in Makassar society.

\section{References}

Aisah, S., \& Albar, M. K. (2020). Budaya Melayu Pattani dalam Kajian Profetik. IBDA: Jurnal Kajian Islam Dan Budaya, 18(1), 1-14.

Astika, I. M., \& Yasa, I. N. . (2014). Sastra Lisan Teori dan Penerapannya. Yogyakarta: Graha Ilmu.

Hartono, H., \& Firdaningsih, F. (2019). Akulturasi Islam dengan Budaya Jawa dalam Ritual Sedekah Laut di Pantai Pedalen Kabupaten Kebumen. IBDA: Jurnal Kajian Islam Dan Budaya, 17(2), 364380.

Hide, K. (2003). Symbol ritual and dementia. Journal of Religious Gerontology, 13(3-4), 77-90.

Leuape, E. S., \& Dida, S. (2017). Dialetika etnografi komunikasi emik-etik pada kain tenun. Jurnal Kajian Komunikasi, 5(2), 147-158.

M'jamtu-Sie, N. (2008). The impact of culture and tradition on attitudes to health in Sierra Leone. Journal of Hospital Librarianship, 6(4), 93-107.

Miedema, S., \& Roebben, B. H. M. (2008). The two contested concepts of culture and tradition in 
religious education. Religious Education, 103(4), 480-492.

Miles, M. B., \& Huberman, M. (1992). Analisis Data Kualitatif: Buku Sumber Tentang Metode-Metode Baru. Jakarta: Universitas Indonesia.

Porter, R. E., \& Samovar, L. . (2004). Suatu Pendekatan terhadap Komunikasi antarbudaya. In D. Mulyana \& D. Rakhmat (Eds.), Komunikasi antarbudaya: Panduan Berkomunikasi dengan OrangOrang Berbeda Budaya. Bandung: Remaja Rosdakarya.

Prasanti, D., \& Sjafirah, N. A. (2017). Makna Simbol Budaya Lokal Bagi Komunitas Tanah Aksara. Komunika: Jurnal Dakwah Dan Komunikasi, 11(2), 198-212.

Putri, I. D. R. (2016). Makna Pesan Tradisi Mappacci Pada Pernikahan Adat Bugis Pangkep di Kelurahan Talaka Kecamatan $M a^{\prime}$ rang. Univeritas Islam Negeri Alauddin Makassar.

Rappe, S. (2016). Nilai-Nilai Budaya pada Upacara Mappaccingdi DesaTibona Kecamatan Bulukumpa Kabupaten Bulukumba. UIN Alauddin Makassar.

Ridwan, M., Hasbollah, T., Mohdar, Y., Sulaeman, S., \& Nur, S. (2020). The Abda'u Ritual: Ethnographic Communication Study of Tulehu Society in the Moluccas, Indonesia. International Journal of Criminology and Sociology, 9, 709-722.

Salam, N. (2016). Tinjauan Hukum Islam tentang Prosesi Perkawinan Adat Makassar di Kecamatan Somba Opu Kabupaten Gowa (Tahun 2015-2016). Universitas Islam Negeri Alauddin Makassar.

Saryono, D. (1998). Representasi Nilai Budaya Jawa dalam Prosa Fiksi Indonesia. Program Pascasarjana IKIP Malang.

Sugiyono. (2010). Metode penelitian pendidikan; Pendekatan kuantitatif, kualitatif, dan RED. Bandung: ALFABETA.

Sulaeman, Mahriani, R., \& Nurdin, A. (2019). Komunikasi Tradisi Abda'u pada Prosesi HewanQurban Adat Tulehu Maluku. KOMUNIKA: Jurnal Dakwah Dan Komunikasi, 13(2), 201-218.

Sulaeman, \& Mulyana, D. (2016). People with Lobster - Claw Syndrome: A Study of Oligodactyly Sufferers and Their Communication Experiences in the Village of Ulutaue, South Sulawesi, Indonesia. Mediterranean Journal of Social Sciences, 7(1), 136-144.

Sulaeman, \& Rijal, M. (2018). Simbolik Komunikasi Ritual Ukuwala Mahiate Masyarakat Islam Mamala Kabupaten Maluku Tengah. Jurnal Kajian Islam Dan Budaya, 16(2), 287-302.

Sulaeman, S., Kamaruzzaman, K., \& Malawat, M. (2019). The Ma'atenu communication rituals of Pelauw Muslims community. Masyarakat, Kebudayaan Dan Politik, 32(4), 426-441.

Sulaeman, S., Rijal, M., Malawat, M., \& Sere, I. (2020). The symbolic communication of the ukuwala mahiate ritual of the indigenous peoples of Mamala, Moluccas, Indonesia. Journal of International Migration and Integration, 1-19.

Sulistyorini, D., \& Andalas, E. . (2017). Sastra Lisan: Kajian Teori dan Penerapannya dalam Penelitian. Malang: Madani.

Umar, M. T. (2020). Islam dalam Budaya Jawa Perspektif Al-Qur'an. IBDA: Jurnal Kajian Islam Dan Budaya, 18(1), 68-86.

Vischer, F. T., \& Yanacek, H. A. (2016). The Symbol. Art in Translation, 7(4), 417-448.

Wahab, M. H. A. (2011). Simbol-Simbol Agama. SUBSTANTIA: Jurnal Ilmu-Ilmu Ushuluddin, 13(1), 7884.

Wahid, S. (2016). Kearifan Adat Istiadat Makassar. Makassar: Arus Timur.

Wikandaru, R., Lasiyo, L., \& Sayuti, S. A. (2018). Rasa Sebagai Prinsip Pertama Ontologi Harmoni dalam Pathet Pergelaran Wayang. Wawasan: Jurnal Ilmiah Agama Dan Sosial Budaya, 3(2), 120-139.

(C) 2020 by the authors. Submitted for possible open access publication under the terms and conditions of the Creative Commons Attribution (CC BY SA) license (https://creativecommons.org/licenses/by-sa/3.0/). 